\title{
THE DISAPPEARANCE OF MALE SECONDARY SEXUAL CHARACTERISTICS IN THE TYPICAL CAVE SPECIES IN TRIPLOPHYSA
}

\author{
Jun LIANG * and Jiang ZHOU ** C.A. \\ * Guizhou Normal University, School of Life Sciences, Guiyang, Guizhou, P. R. C., P. O. Box, \\ CN-550001, 1597556942@qq.com \\ ** Guizhou Normal University, School of Life Sciences, Guiyang, Guizhou, P. R. C., P. O. Box, \\ CN-550001, zhoujiang@ioz.ac.cn
}

DOI: 10.2478/trser-2019-0005

KEYWORDS: Triplophysa, male secondary sexual characteristics, Guizhou Province China.

\section{ABSTRACT}

It was suggested that the darkness environment would influence the fishes' morphology, not only the barbells, snout, but also the male secondary sexual features. This paper reported that the three typical cave dwelling fish species of Triplophysa did not show these sexual morphological traits, such as Triplophysa lewangensis, Triplophysa nasobartula and Triplophysa zhenfengensis collected in Guizhou Province, meanwhile, there were not the description on the traits about the 11 typical cave dwelling species of this genus in Guangxi Province.

RESUMÉ: La disparition des caractères sexuels secondaires masculins dans l'espèce typique des cavernes du genre Tryplophysa.

Il a été suggéré que l'environnement de l'obscurité influencerait la morphologie des poissons, non seulement les barbillons, le museau, mais aussi les caractéristiques sexuelles secondaires masculines. Cet article rapporte que les trois espèces de poissons troglodytes typiques de Triplophysa tels que Triplophysa lewangensis, Triplophysa nasobartula et Triplophysa zhenfengensisrécoltés dans la province de Guizhou, n’ont pas présenté ces caractères morphologiques sexuels, qu même temps n’ayant pas de description sur les traits caractéristiques des 11 espèces vraies troglodytes de ce genre de la province de Guangxi.

REZUMAT: Dispariția caracterelor sexuale secundare masculine la speciile troglobionte tipice din genul Tryplophysa.

S-a sugerat că mediul lipsit de lumină ar influența morfologia peștilor, nu numai la nivelul mustăților, rostrului, dar și caracteristicile sexuale secundare masculine. Articolul a concluzionat că cele trei specii de pești din genul Triplophysa, tipice pentru mediul cavernicol, nu au prezentat aceste trăsături morfologice sexuale, precum Triplophysa lewangensis, Triplophysa nasobartula și Triplophysa zhenfengensis colectate în provincia Guizhou, în timp ce nu există o descriere a trăsăturilor celor 11 specii troglobionte tipice din acest gen care sunt întâlnite în Provincia Guangxi. 


\section{INTRODUCTION}

Rendahl (1933) established Triplophysa hutjertjuensis as a model species, and Bănărescu and Nalbant (1975) classified Triplophysa into two genera: Hedinichthy and Triplophysa. Zhu Songquan (1989) combined them in one genus, Triplophysa, based on the structural characteristics of the position of the male secondary sexual features of Triplophysa and the shape of the small spines. Triplophysa is the larger genus in Nemacheilidae. Till now 197 species have been described (Eschmeyer et al., 2017), of which more than 100 species have been distributed in China (Zhang Chunguang et al., 2015). In addition, there are 29 species of typical caves species in Triplophysa in China Triplophysa (Tab. 1), eight species in Yunnan, six species in Guizhou, 13 species in Guangxi, and one species in Chongqing and one species in Hunan.

There are not only surface species, but also 29 species that live in caves. However, the characteristics of male secondary sexual characteristics have not been found in the description of these cave species. Therefore, the species of Guizhou Province's caves (Fig. 1), such as Triplophysa lewangensis, Triplophysa zhenfengensis, and Triplophysa nasobartula, were inspected to determine if the male secondary sexual characteristics were present.

The surface species' adult males have the secondary sexual characteristics mainly on the sides of the head and the pectoral fins (Zhu Songquan, 1989; Hou Feixia, 2010). The phenotype could be divided into: 1 . The upper and lower parts of the infraorbital line are thickened with spines (e.g. T. minxianensis). 2. No spines in the upper and lower parts of the infraorbital line, only thickened (e.g. T. daqiaoensis (Fig. 2-P1). 3. Only the upper part thickened, and no spike (e.g. T. stenura (Fig. 3-P2). 4. Only the upper part thickened and has spines (e.g. T. stoliczkae) (Fig. 4-P3) have changes in pectoral fins (Hou Feixia et al., 2010). Sexual characteristics are divided into: 1 . The pectoral fin masks are thickened with pads with spiny spines (e.g. T. daqiaoensis. (Fig. 5-P11) 2. Thick padded pectoral fins on back, no spikes (e.g. T. markehenensis) (Fig. 5-P12). 3. The pad on the back of the pectoral fin is not obvious, and there are no spines (e.g. T. markehenensis (Fig. 5-P13). (Hou F. X. et al., 2010)

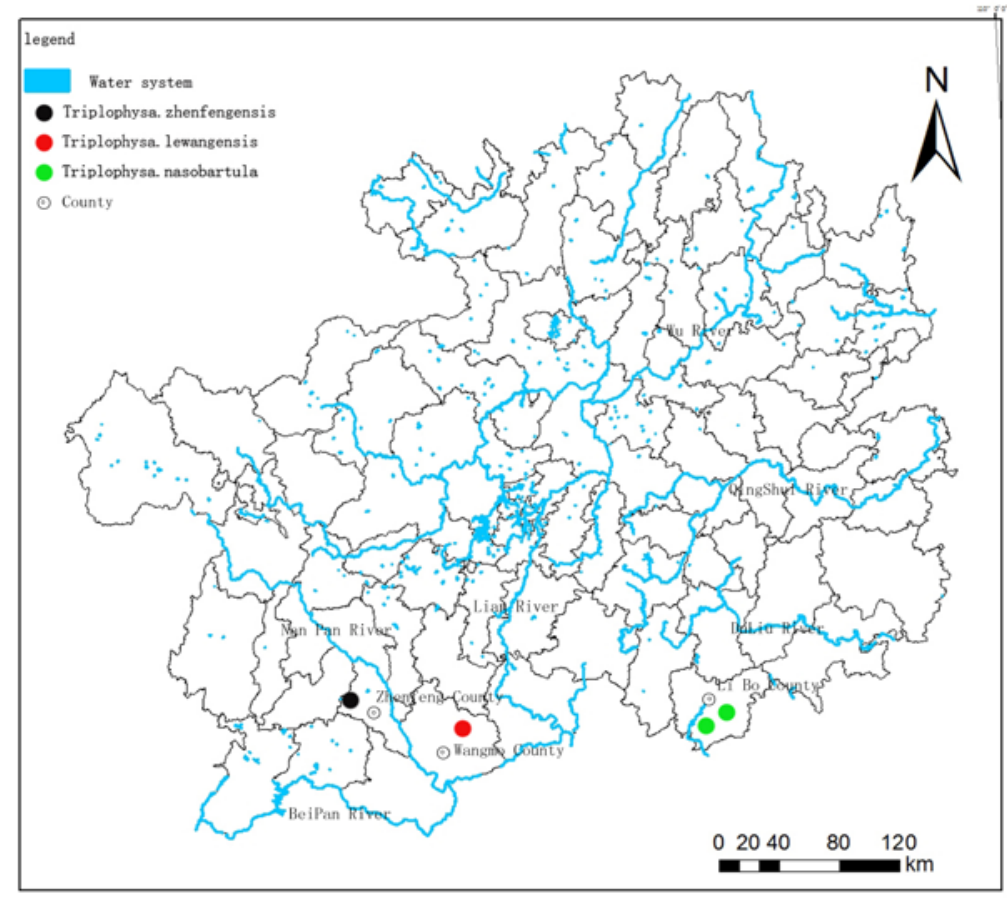

Figure 1: Studied areas. 


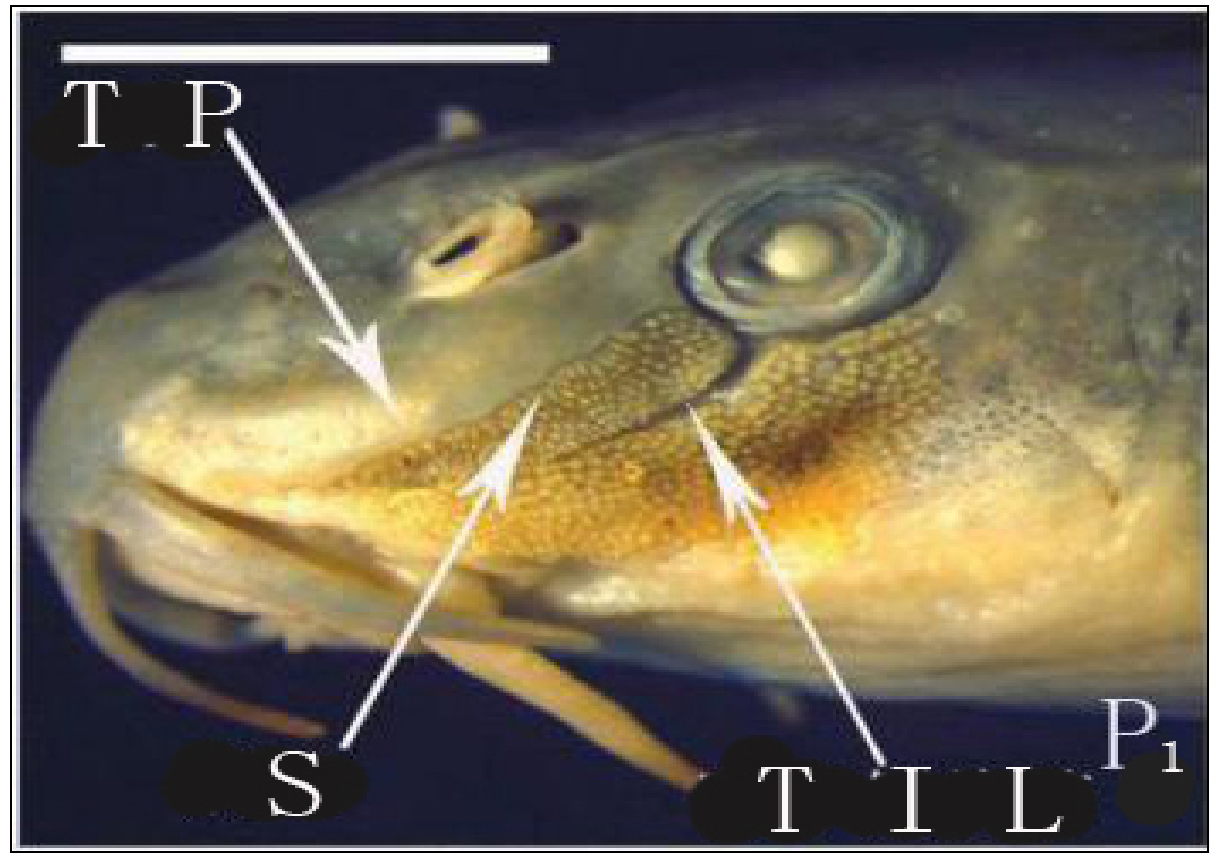

Figure 2: Triplophysa daqiaoensis; Lateral view of head of Triplophysa males, showing the secondary sexual characters; $\mathrm{T} \mathrm{P}=$ Thickended pad; $\mathrm{S}=$ Spines;

T I L = The infraorbital line; Scalebars = five mm (photo Hou F. X. et al., 2010).

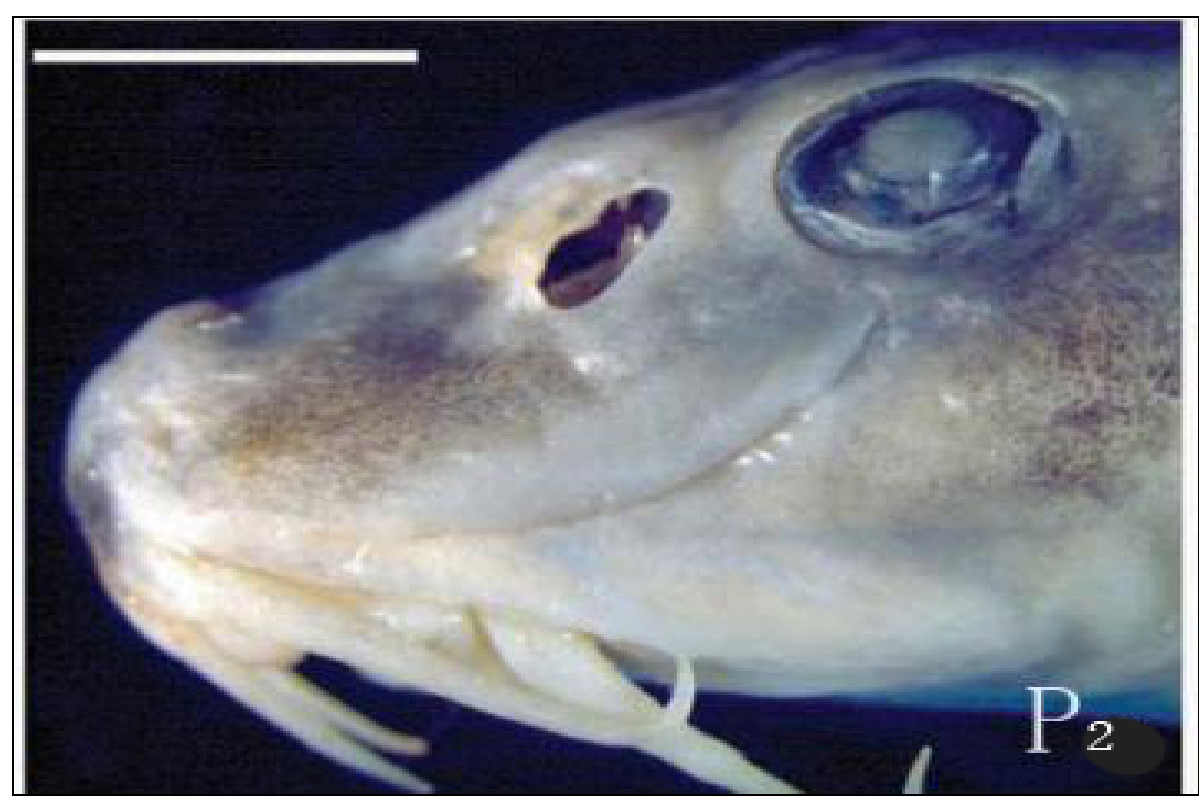

Figure 3: Triplophysa stenura; Lateral view of head of Triplophysa males, showing the secondary sexual characters; $\mathrm{T}$ P = Thickended pad; $\mathrm{T}$ I L = The infraorbital line; Scalebars = five mm (photo Hou F. X. et al., 2010). 


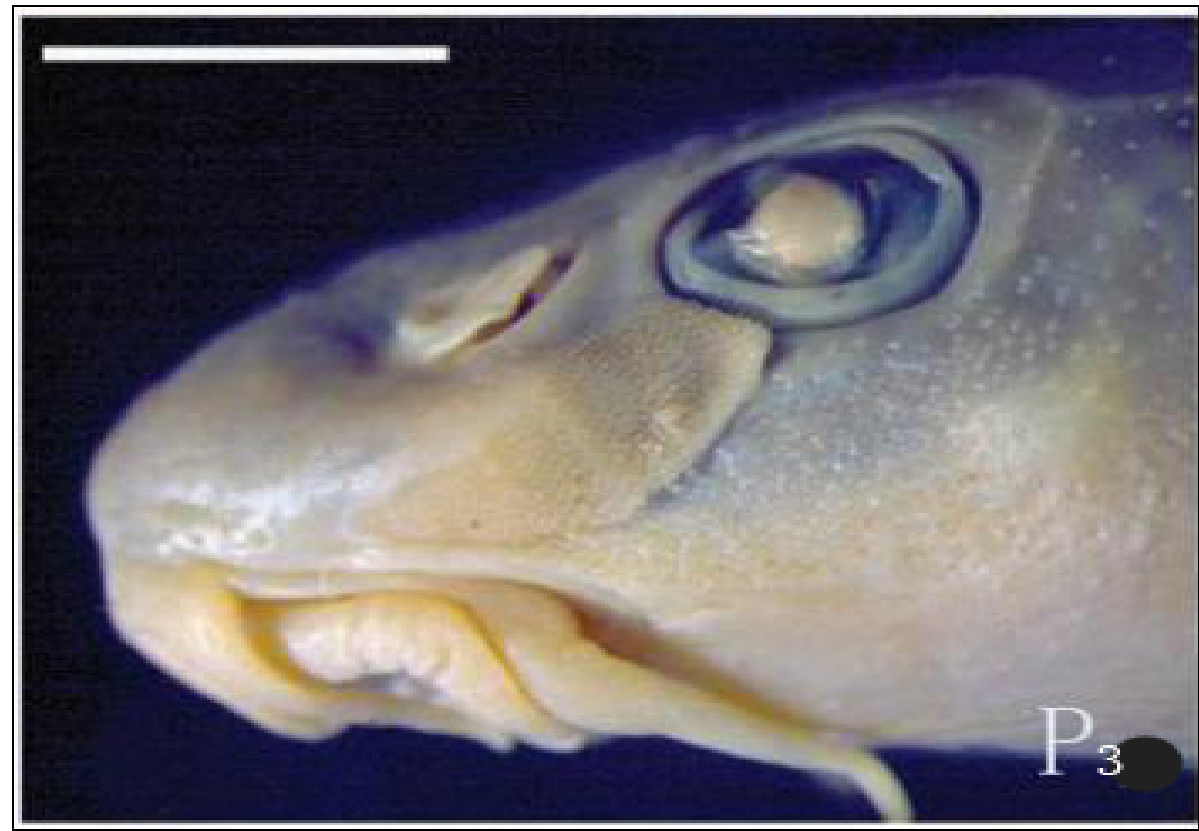

Figure 4: Triplophysa stoliczkae; Lateral view of head of Triplophysa males, showing the secondary sexual characters; $\mathrm{T} \mathrm{P}=$ Thickended pad; $\mathrm{S}=$ Spines;

T I L = The infraorbital line; Scalebars = five mm (photo Hou F. X. et al., 2010).

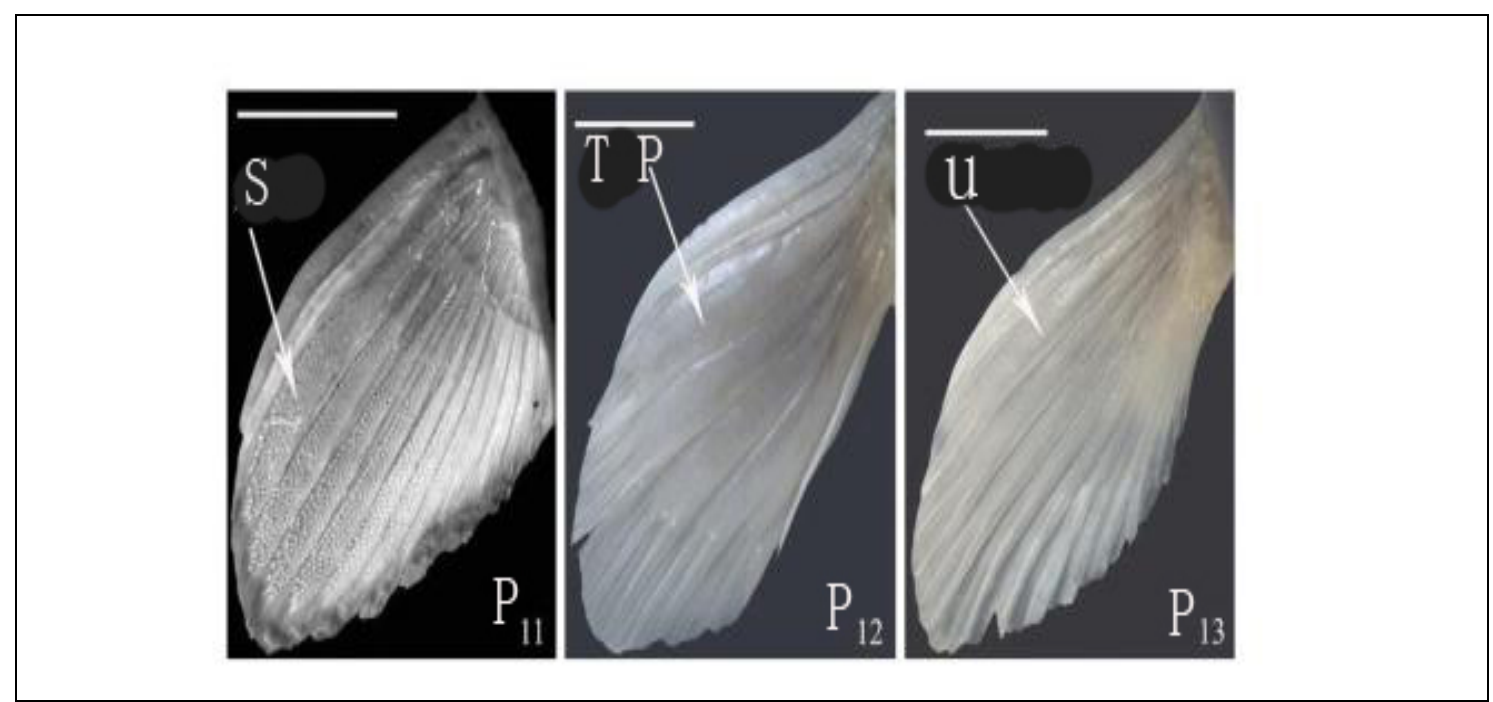

Figure 5: Dorsal view of pectoral fin of Triplophysa males, showing secondary sexual characters; $\mathrm{S}=$ Spines; $\mathrm{T} \mathrm{P}=$ Thickened pad; $\mathrm{U}=$ Unobvious; $\mathrm{P} 11$ Triplophysa daqiaoensis; P 12-P 13 Triplophysa markehenensis; Scalebars = five mm (photo Feixia et al., 2010). 
Table 1: The species distribution of the typical genus Triplophysa in China.

\begin{tabular}{|c|c|}
\hline Species & Geographical distribution \\
\hline $\begin{array}{l}\text { Triplophysa aluensis } \\
\text { (Li W. X. and Zhu Z. G., 2000) }\end{array}$ & Alu ancient cave, Luxi County, Yunnan Province \\
\hline $\begin{array}{l}\text { Triplophysa gejiuensis } \\
\text { (Chu X. L., et al., 1979) }\end{array}$ & Gejiu City, Yunnan Province, China \\
\hline $\begin{array}{l}\text { Triplophysa qiubeiensis } \\
\text { (Li W. X., et al., 2008) }\end{array}$ & Nijiao Village, Qiubei County, Yunnan Province \\
\hline $\begin{array}{l}\text { Triplophysa shilinensis } \\
\text { (Chen Y. R., et al., 1992) }\end{array}$ & $\begin{array}{l}\text { Boyi Village near Shilin in Lunan County, } \\
\text { Yunnan Province }\end{array}$ \\
\hline $\begin{array}{l}\text { Triplophysa xiangshuingensis } \\
\text { (Li W. X., 2004) }\end{array}$ & Shilin County, Yunnan Province \\
\hline $\begin{array}{l}\text { Triplophysa yunnanensis } \\
\text { (Yang, 1990) }\end{array}$ & Yiliang County, Yunnan Province \\
\hline $\begin{array}{l}\text { Triplophysa tianxingensis } \\
\text { (Yang H. F., et al., 2016) }\end{array}$ & Qiubei County, Yunnan Province \\
\hline $\begin{array}{l}\text { Triplophysa xichouensis } \\
\text { (Liu S. W., et al., 2017) }\end{array}$ & Xichou County, Yunnan Province \\
\hline $\begin{array}{l}\text { Triplophysa nasobartula } \\
\text { (Wang D., and Li D., 2001) }\end{array}$ & $\begin{array}{l}\text { Wengang Township and Dongtang Township, Libo County, } \\
\text { Guizhou Province }\end{array}$ \\
\hline $\begin{array}{l}\text { Triplophysa zhenfengensis } \\
\text { (Wang D., and Li D., 2001) }\end{array}$ & Longchang Town, Zhenfeng County, Guizhou Province \\
\hline $\begin{array}{l}\text { Triplophysa longliensis } \\
\text { (Ren Q., et al., 2012) }\end{array}$ & Longli County, Guizhou Province \\
\hline $\begin{array}{l}\text { Triplophysa jiarongensis } \\
\text { (Lin Y., et al., 2012) }\end{array}$ & Libo County, Guizhou Province \\
\hline $\begin{array}{l}\text { Triplophysa longibarbatula } \\
\text { (Chen Y. R., et al., 1998) }\end{array}$ & Libo County, Guizhou Province \\
\hline $\begin{array}{l}\text { Triplophysa lewangensis } \\
\text { (unpublished) }\end{array}$ & Lewang Town, Wangmo County, Guizhou Province \\
\hline $\begin{array}{l}\text { Triplophysa nandanensis } \\
\text { (Lan J. H., et al., 1995, 2013) }\end{array}$ & $\begin{array}{l}\text { Mayang Village, Six Village Town, Nandan County, } \\
\text { Guangxi Province }\end{array}$ \\
\hline $\begin{array}{l}\text { Triplophysa tianeensis } \\
\text { (Chen X. Y., et al., 2004) }\end{array}$ & $\begin{array}{l}\text { Number eight hole, Bala Township, Tiane County, } \\
\text { Guangxi Province }\end{array}$ \\
\hline $\begin{array}{l}\text { Triplophysa lingyunensis } \\
\text { (Liao J. W., et al., 1997) }\end{array}$ & $\begin{array}{l}\text { Sha hole, Mawang Village, Sicheng Town, Lingyun } \\
\text { County, Guangxi Province }\end{array}$ \\
\hline $\begin{array}{l}\text { Triplophysa huapingensis } \\
\text { (Zheng L. P., 2012) }\end{array}$ & Huaping Village, Leye County, Guangxi Province \\
\hline $\begin{array}{l}\text { Triplophysa longipectoralis } \\
\text { (Zheng L. P., 2009) }\end{array}$ & Xunle Township, Huanjiang County, Guangxi Province \\
\hline $\begin{array}{l}\text { Triplophysa macrocephala } \\
\text { (Yang J., et al., 2012) }\end{array}$ & Bawei Township, Nandan County, Guangxi Province \\
\hline
\end{tabular}


Table 1 (continued): The species distribution of the typical genus Triplophysa in China.

\begin{tabular}{|l|l|}
\hline $\begin{array}{l}\text { Trjplophysa lihuensis } \\
\text { (Wu T. J., et al., 2012) }\end{array}$ & Lihu Town, Nandan County, Guangxi Province \\
\hline $\begin{array}{l}\text { Triplophysa huanjiangensis } \\
\text { (Yang J., et al., 2011) }\end{array}$ & Chuanshan Town, Huanjiang County, Guangxi Province \\
\hline $\begin{array}{l}\text { Triplophysa langpingensis } \\
\text { (unpublished) }\end{array}$ & Langping Township, Tianlin County, Guangxi Province \\
\hline $\begin{array}{l}\text { Triplophysa fengshanensis } \\
\text { (unpublished) }\end{array}$ & Lintong Township, Fengshan County, Guangxi Province \\
\hline $\begin{array}{l}\text { Triplophysa dongganensis } \\
\text { (unpublished) }\end{array}$ & $\begin{array}{l}\text { Tonggan Village, Chuanshan Town, Huanjiang County, } \\
\text { Guangxi Province }\end{array}$ \\
\hline $\begin{array}{l}\text { Triplophysa tianlinensis } \\
\text { (Li J., et al., 2017a) }\end{array}$ & Tianlin County, Guangxi Province \\
\hline $\begin{array}{l}\text { Triplophysa luochengensis } \\
\text { (Li J., et al., 2017b) }\end{array}$ & Luocheng County, Guangxi Province \\
\hline $\begin{array}{l}\text { Triplophysa rosa } \\
\text { (Huang J., et al., 2013) }\end{array}$ & Stove Town, Wulong County, Chongqing City \\
\hline $\begin{array}{l}\text { Triplophysa xiangxiensis } \\
\text { (He L., et al., 2006) }\end{array}$ & $\begin{array}{l}\text { Huoyan Township, Longshan County, Xiangxi } \\
\text { Autonomous Prefecture, Hunan Province }\end{array}$ \\
\hline
\end{tabular}

\section{MATERIAL AND METHODS}

Triplophysa lewangensis, collecting place Lewang Town, Wangmo County, Guizhou Province, specimen number 28.

Triplophysa nasobartula, collecting place Lijiangshui Cave, Jiarong Town, Libo County, Guizhou Province, specimen number 22.

Triplophysa zhenfengensis, collecting place Shuangrufeng Scenic, Zhenfeng County, Guizhou Province, specimen number 12.

Determination and selection of adult individuals, according to the report of Wang and $\mathrm{Li}$ (2001), the total length of $34 \mathrm{~mm}$, males with atypical cave types over $28 \mathrm{~mm}$ have secondary sexual characteristics. Therefore, this study selected specimens with body length greater than $30 \mathrm{~mm}$ as comparatively mature individuals.

Three types of Triplophysa specimens with body length greater than $28 \mathrm{~mm}$ were examined.

No padding and spines were found on the lateral side of all Triplophysa crickets. Pectoral fins also found no thickened pads and spines. It was found that there are 17 males in Triplophysa lewangensis. Eleven Triplophysa nasobartula has nine males. 12 Triplophysa zhenfengensis has eight males, and four females. Three Triplophysa body length measurements were as is following: Triplophysa lewangensis body length 27.71-54.81 mm, full length 42.33-56.32 mm; Triplophysa nasobartula body length 50.70-91.31 mm, full length 62.46-109 mm; Triplophysa zhenfengensis body length 57.47-101.50 mm, full length 65.79-123.18 mm. 


\section{RESULTS AND DISCUSSION}

Comparative results of morphological characteristics of the infraorbital line side of three species of genus Triplophysa in Guizhou Province.
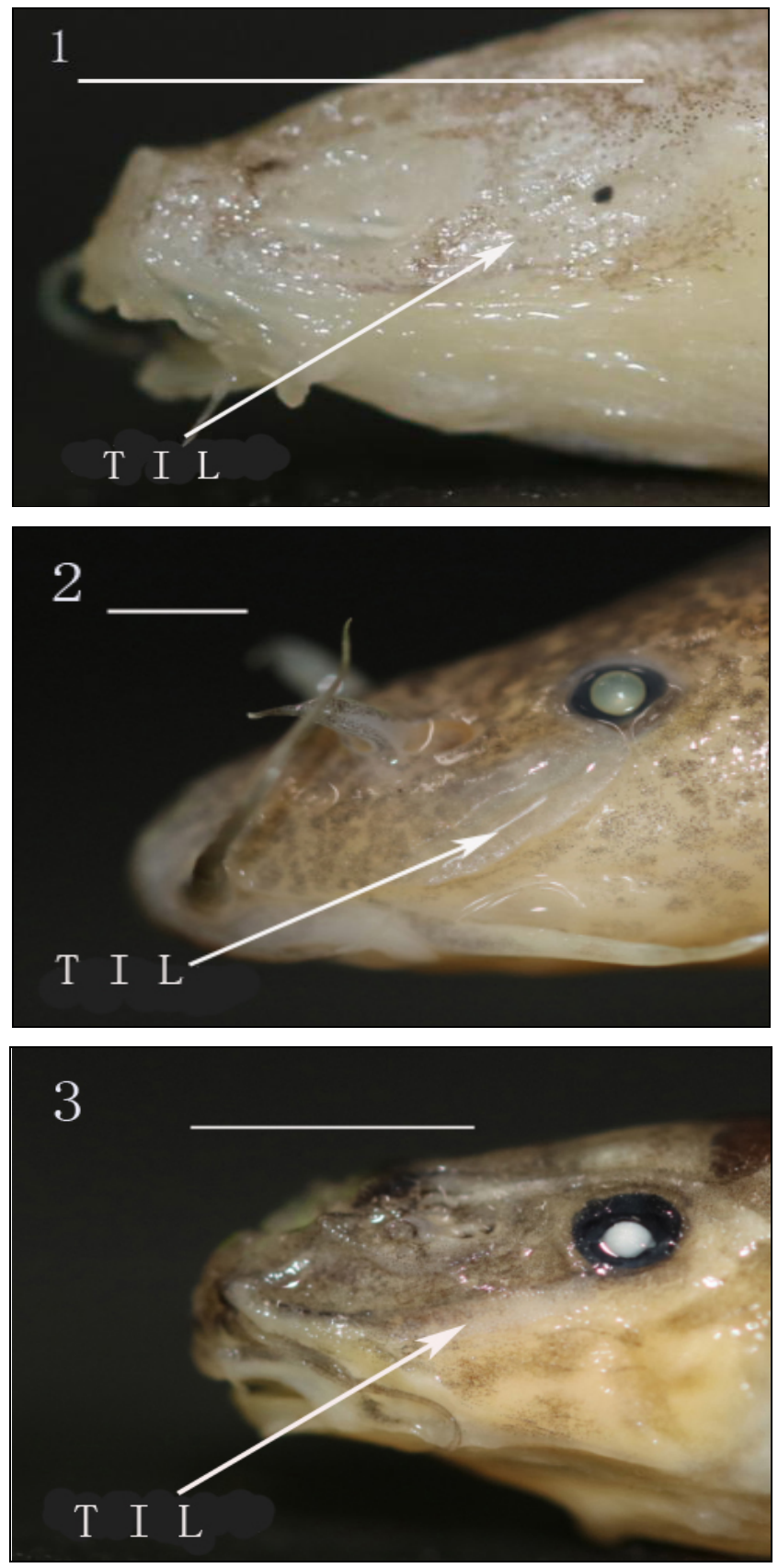

Figure 6: Infraorbital line; 1. Triplophysa lewangensis; 2. Triplophysa nasobartula; 3. Triplophysa zhenfengensis; Scalebars = five $\mathrm{mm}$; TIL = the infraorbital line. 
Comparison of morphological characteristics of pectoral fins of three kinds of genus caves in Guizhou Province.
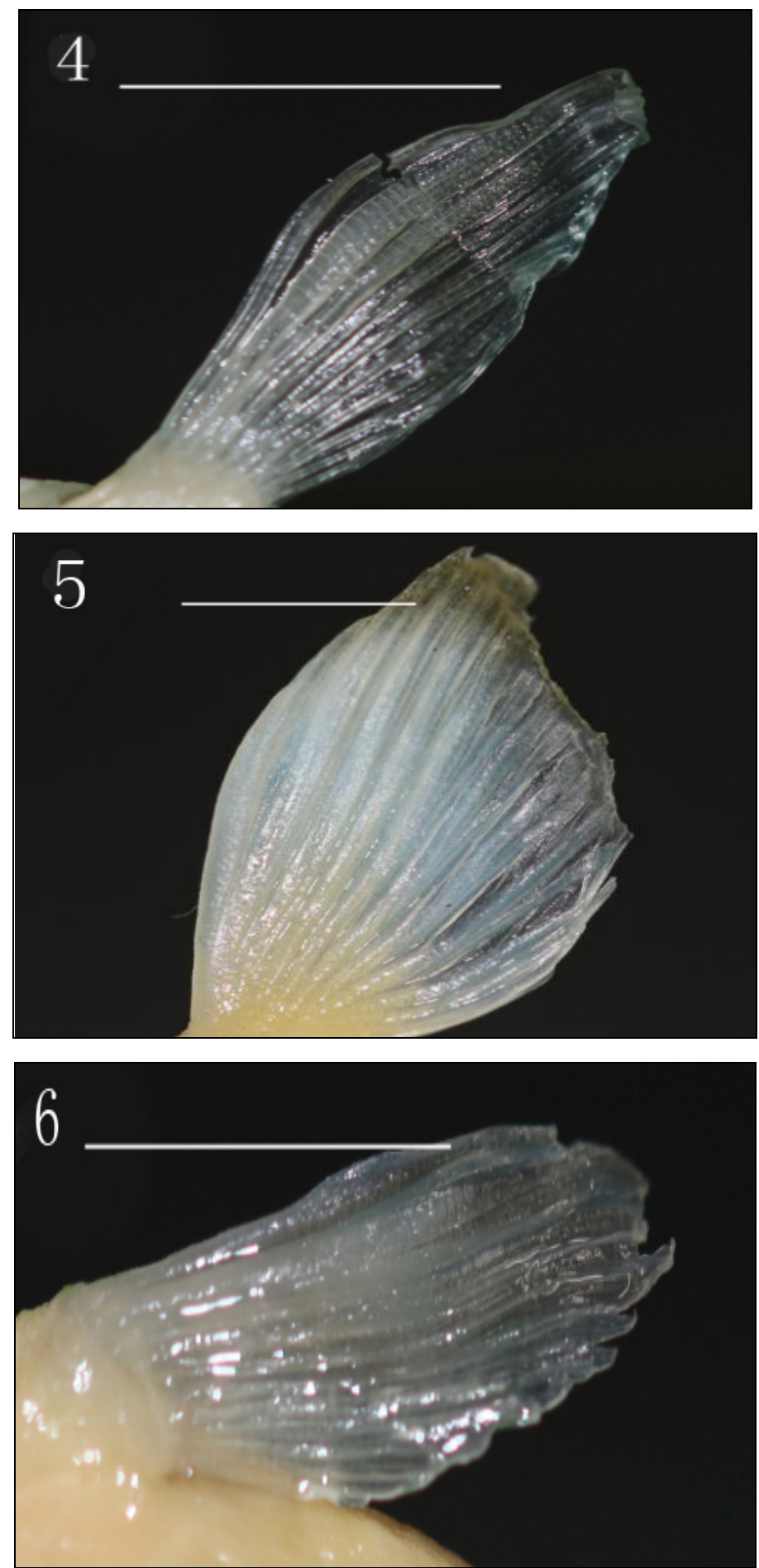

Figure 7: Pectoral fins; 4. Triplophysa lewangensis; 5. Triplophysa nasobartula;

6. Triplophysa zhenfengensis; Scalebars = five $\mathrm{mm}$. 
The secondary sexual characteristics of male individuals in three cave species of Triplophysa in Guizhou Province.

Among the three Triplophysa cave species with typical male individuals we observed: 1. Triplophysa lewangensis individual had smaller white transparent back with a little stain that does not recede, compared with the first two types of both sides of head lateral morphology. The subaxillary line tube is not obvious. There was no thickening of the upper and lower leaves of the male zygomatic line at the cheeks of the male, and no spines were distributed (Fig. 6). The thickened pectoral fins have disappeared.

The spines have also disappeared (Fig. 7). 2. The upper and lower mesophyll pads of the male Triplophysa nasobarbatula, and the inferior lateral line of male cheeks have disappeared. No spines distribution (Fig. 6). The thickened pectoral fins have disappeared, and the spines have disappeared (Fig. 7). 3. Triplophysa zhenfengensis male genital cheeks under the lateral line of the upper and lower leaves of the pad have disappeared; also, no spines distribution was observed (Fig. 6). The pectoral fin cushion has disappeared along with the spines (Fig. 7).

The sex determination of fish is very complicated. The current study on the sex determination of fish is still at an exploratory stage. For those who have obvious secondary sexual characteristics, wait until sexual maturity. And in the breeding season, we can accurately distinguish their sex by morphology. The disappearance of male secondary sexual characteristics in cave species will undoubtedly bring great difficulties to the population ecology studies of cave fishes. Therefore, it is necessary to study a new technical means to identify the gender of cave fish. At present, SD genes in fish with $\mathrm{XX} / \mathrm{XY}$ sex determination system, five other SD-related genes, such as gsdf in Oryzias luzonensis, sox3 in Oryzias dancena, amhr2 in Takifugu rubripes, Amhy in Odontesthes hatchery and sdY in Oncorhynchus mykiss, were respectively identified from several teleost fish with XX/XY sex determination system (Mei and Gui, 2015). It is gradually progressing during the study of fish sex determination. But until now, the discovery of such a gene, which is a very stable characteristic of the sex determination of male fish, has not yet been established. Therefore, this work is very worthwhile to carry out.

According to Zhu Songquan's research (1989), the surface species of the genus Triplophysa have the habit of chasing after breeding. It is presumed that the special structure of the male and pectoral fins contributes to the effective attachment of females in the flowing water environment and improves the fertilization rate. However, the disappearance of male secondary sexual characteristics in the typical cave species in Triplophysa is a reaction to the influence of the environment on the morphological characteristics of Triplophysa. Therefore, courtship behavior for typical cave fish is a very interesting issue.

\section{CONCLUSIONS}

Triplophysa cave fish species have lost the secondary sexual characteristics because of long-term living in the dark cave environment. 


\section{ACKNOWLEDGEMENTS}

The data in this research comes from the database of National Digital-Museum of Animal Specimens. This project was supported by key project of Science-technology basic condition platform from The Ministry of Science and Technology of the People's Republic of China (grant number 2005DKA21402). In addition, thanks to my supervisor, Prof. Zhou Jiang of Guizhou Normal University, the guidance for writing this paper, and in the follow-up article's revision gives valuable advice and help. Secondly, we would like to thank the Animal Science Laboratory of Guizhou Normal University for its specimens. Thirdly, we would like thank Mr. Liu Tao, Mr. Chen Jian, Mr. Gao Kai and Miss. Wen Huamei for their hard field work. 


\section{REFERENCES}

1. Bănărescu P. and Nalbant T., 1975 - A collection of Cyprinoidei from Afghanistan and Pakistan with description of a new species of Cobitidae (Pisces: Cypriniformes), Mitteilungen aus dem Hamburgischen Zoologischen Museum und Institut, 72, 5, 241-248.

2. Chen Y. R., Yang J. X. and Xu G. C., 1992 - Discovery of the blind triplophysa of Stone Forest in Yunnan and its taxonomic status, Zoological Research, 1, 17-23. (in Chinese)

3. Chen Y. R., Yang J. X., Sgate B. and Alan G., 1998 - Sike, loach and its character evolution, Zoology Research, 01, 59-63. (in Chinese)

4. Chen X. Y., Cui G. H. and Yang J. X., 2004 - A description of a new burrowing genus of the genus Polygonum in Guangxi Triplophysa, Zoology Research, 3, 227-231. (in Chinese)

5. Chu X. L., Chen Y. R., 1979 - A new blind cobitid fish (Pisces, Cypriniformes) from subterranean waters in Yunnan, China, Acta Zoologica Sinica, 25, 3, 285-287. (in Chinese)

6. Eschmeyer W. N., Fricke R. and Laan R. (eds), 2017 - Catalog of fishes: genera, species, references, electronic version, updated 30 March 2017, http://researcharchive.calacademy.org/ research/ichthyology/catalog/fishcatmain, accessed 1st April 2017.

7. He L., Wang X. G., Chen Q. C. and Xiang J. Z., 2006 - Morphological description of Triplophysa xiangxiensis, Freshwater Fisheries, 04, 56-58. (in Chinese)

8. Hou F. X., He C. L., Zhang X. F. and Song Z. B., 2010 - The secondary male sexual characteristics in Triplophysa genus, Animal Classification Journal, 35, 1, 101-107. (in Chinese)

9. Huang J., Peng Z. G. and Wang Z. J., 2013 - A comparison of the general anatomy of the camphor of Triplophysa bleekeri and Rose triplophysa, Journal of Southwest China Normal University, Natural Science Edition, 38, 03, 94-100. (in Chinese)

10. Lan J. H., Yang J. X. and Chen Y. R., 1995 - Two new species of the subfamily loach (subfamily Cyprini) from Guangxi (cyprinid: loach), Zoological society, 03, 366-372. (in Chinese)

11. Lan J. H., Gan X., Wu T. J. and Yang J., 2013 - Guangxi Cave Fish, Science Press, 1, 103-139. (in Chinese)

12. Li W. X. and Zhu Z. G., 2000 - A description of a new species in the genus Geomorpha in the cave triplophysa, Journal of Yunnan University, Natural Sciences Edition, 5, 396-398. (in Chinese)

13. Li W. X., 2004 - The description of three new species of marine carps in Yunnan Province, Journal of Jishou University, Natural Science Edition, 3rd. (in Chinese)

14. Li W. X., Yang H. F. and Chen H., 2008 - A new species of blindfish in the Yunnan triplophysa, China: a blind tirplophysa Qiubei tirplophysa, Tao Chengpeng, Qi Shouqing and Han Fei, Zoology Research, 29, 06, 674-678. (in Chinese)

15. Li J., Lan J. H., Chen X. Y. and Du L. N., 2017a - Description of Triplophysa luochengensis sp. nov. (Teleostei: Nemacheilidae) from a karst cave in Guangxi, China, Journal of Fish Biology, doi:10.1111/jfb.13364.

16. Li J., Li X. H., Lan J. H. and Du L. N., 2017b - A new troglobitic loach Triplophysa tianlinensis (Teleostei: Nemacheilidae) from Guangxi, China, Ichthyology Research, 64, 295300.

17. Liao J. W., Wang D. Z. and Luo Z. F., 1997 - A new species and a new subspecies of the southern genus fish (Scorpionidae: Polygonidae: Acrididae), Journal of Zunyi Medical College, 20, 2-3, 4. (in Chinese)

18. Lin Y., Li C. and Song J. K., 2012 - A new species of Lygata ocellatus in Guizhou Province, China (Cyprinidae, Crested-claw), Acta Zootaxonomica Sinica, 37, 3, 640-647. (in Chinese)

19. Liu S. W., Pan X. F., Yang J. X. and Chen X. Y., 2017 - A new cave-dwelling loach, Triplophysa xichouensis sp. nov. (Teleostei Nemacheilidae) from Yunnan, China, Journal of Fish Biology, 90, 834-846. 
20. Mei J. and Gui J. F., 2015 - Genetic basis and biotechnological manipulation of sexual dimorphism and sex determination in fish, Science China Life Sciences, 58, 2, 124-136.

21. Ren Q., Yang J. X. and Chen X. Y., 2012 - A new species of the genus Triplophysa. (in Chinese)

22. Rendahl H., 1933 - Studien uber innerasiatische Fische, Archieves for Zoology, 25, 11, 1-51. (in German)

23. Wang D. Z. and Li D. J., 2001 - Two new species of the genus Polygonum in the Guizhou triplophysa (Scorpiformes: Polygonidae: Acrididae), Journal of Animal Taxonomy, 1, 98-101. (in Chinese)

24. Wu T. J., Yang J. and Lan J. H., 2012 - A new blind loach, Triplophysa lihuensis, (Teleostei: Balitoridae), from Guangxi, China, Zoological Studies, 51, 6, 874-880.

25. Yang J. X., 1990 - Nemacheiline, in Chu X. L. and Chen Y. R., The Fishes of Yunnan, China, Part 2, Scientific Press, Beijing, 54-60. (in Chinese)

26. Yang J., Wu T. J. and Lan J. H., 2011 - A new blind loach species, Triplophysa huanjiangensis (Teleostei: Balitoridae), from Guangxi, China, Zoological Research, 32, 5, 566-571.

27. Yang J., Wu T. J. and Yang J. X., 2012 - A new cave-dwelling loach, Triplophysa macrocephala (Teleostei: Cypriniformes: Balitoridae), from Guangxi, China, Environmental Biology of Fishes, 93, 169-175.

28. Yang H. F., Li W. X and Chen Z. M., 2016 - A new cave species of the genus Triplophysa from Yunnan, China, Zoological Research, 37, 5, 296-300.

29. Zhu S. Q., 1989 - Chinese loach, Jiangsu science and Technology Press, Nanjing. (in Chinese)

30. Zhang C. G., Zhao Y. H. and Xing Y. C., 2015 - Fish species and distribution in China, Beijing, Science Press. (in Chinese)

31. Zheng L. P., Du L. N., Chen X. Y. and Yang J. X., 2009 - A new species of genus Triplophysa (Nemacheilinae: Balitoridae), Triplophysa longipec-toralis sp. nov., from Guang-China, Environmental Biology of Fishes, 85, 221-227.

32. Zheng L. P., Yang J. X. and Chen X. Y., 2012 - A new species of Triplophysa (Nemacheilidae: Cypriniformes), from Guangxi, southern China, Journal of Fish Biology, 80, 831-841. 